\section{Conclusion}

Finally, we suggest that a more systematic approach to the assessment of possible malnutrition should be adopted in hospitals dealing with admission of acutely ill elderly patients. The detection of occult malabsorption is neither very time consuming nor extremely traumatic for the individual patients. After initial clinical evaluation and a simple haematological and biochemical work up the diagnosis of occult malabsorption may usually be made by a barium meal and follow through examination plus the ${ }^{14} \mathrm{C}$-glycocholic acid breath test.

We acknowledge the considerable help given to us in the compilation of this study by Ms B Davidson (dietitian); Dr K Bartlett and Mr M Barton (measurements of volatile fatty acids); and Mrs A Asch (preparation of manuscript). We are grateful to Newcastle upon Tyne DHA Scientific and Research Committee for financial aid.

\section{References}

1 Shank RE. Nutritional characteristics of the elderly-an overview. In: Rockstein M, Sussman ML, eds. Nutrition, longevity and aging. New York: Academic Press, 1976:9-28.

2 Department of Health and Social Security. A nutrition survey of the elderly: report by the panel on nutrition of the elderly. Rep Health Soc Subj (Lond) 1972; No 3

${ }^{3}$ Montgomery RD, Haeney MR, Ross IN, et al. The ageing gut: a study of intestinal absorption in relation to nutrition in the elderly. $Q \mathcal{F} \mathrm{Med}$ 1978;47:197-211.

4 Jeliffe DB. Assessment of the nutritional status of the community. Geneva: World Health Organisation, 1966.

${ }^{5}$ Sleisenger MH, Fordtran JS. Gastrointestinal disease. 2nd ed. Philadelphia : W B Saunders \& Co, 1978.

${ }^{6}$ Spiro HM. Clinical gastroenterology. 2nd ed. New York: Macmillan, 1977.

${ }^{7}$ McEvoy AW, James OFW. Anthropometric indices in normal elderly subjects. Age Ageing 1982;11:97-100.

${ }^{8}$ Uauy, R. Scrimshaw NS, Rand WM, et al. Human protein requirements: obligatory urinary and faecal losses, and the factorial estimation of protein needs in elderly males. $\mathcal{F}$ Nutr 1978;108:97-103.

${ }^{-}$Newcomer AD, Hofmann AF, Di Magno EP, et al. Triolein breath test. A sensitive and specific test for fat malabsorption. Gastroenterology $1979 ; 79: 6-13$.

10 McEvoy A. Investigation of intestinal malabsorption in the elderly. In: Grimley Evans JG, Caird F, eds. Advanced geriatric medicine 2. London: Pitman, 1982:91-9.

"Ingham HR, Dutton J, Sisson PR, et al. An aid to the preliminary identification of non-sporing anaerobes. $\mathcal{F}$ Clin Pathol 1978;31:806-7.

12 Cruikshank R, Duguid JP, Marmion BP, et al. In: Medical microbiology. 12th ed. Vol 2. Edinburgh: Churchill Livingstone 1975:482.

${ }^{13}$ Chernov AJ, Doe WF, Gompertz D. Intrajejunal volatile fatty-acids in the stagnant loop syndrome. Gut 1972;13:103-6.

14 Gill GV, Wheatley K. "Off their feet"- geriatric syndrome. Practitioner $1982 ; 226: 966-9$.

15 Cotton PB. ERCP progress report. Gut 1977;18:316-41.

${ }^{16}$ Price HL, Gazzard BG, Dawson AM. Steatorrhoea in the elderly. Br Med f 1977 ; i : 1582-4.

17 Ryder JB. Steatorrhoea in the elderly. Gerontologia Clinica 1963;5:30-7.

1* Gorbach SL, Tabaqchali S. Bacteria, bile and the small bowel. Gut 1969; 10:963-72.

${ }^{19}$ Neale G, Gompertz D, Schonsby $\mathrm{H}$, et al. The metabolic and nutritional consequences of bacterial overgrowth in the small intestine. $\mathrm{Am} \mathcal{F} \mathrm{Clin}$ Nutr 1972;25:1409-17.

20 Drude RB, Hines C. The pathophysiology of intestinal bacterial overgrowth syndromes. Arch Intern Med 1980;140:1349-52.

${ }^{21}$ Donaldson RM. Small bowel bacterial overgrowth. Adv Intern Med 1970;16:191-212.

${ }^{22}$ King CE, Toskes PP. Small intestinal bacterial overgrowth. Gastroenterology $1979 ; \mathbf{7 6}: 1035-55$

${ }^{23}$ Gracey MS. Nutrition, bacteria and the gut. Br Med Bull 1981;37:71-5.

${ }^{24}$ Roberts SH, James O, Jarvis EH. Bacterial overgrowth syndrome without "blind loop": a cause for malnutrition in the elderly. Lancet 1977;ii: 1193-5.

25 Clark ANG. Deficiency states in duodenal diverticular disease. Age Ageing 1972;1:14-23.

26 Tabaqchali S, Hatzioannou J, Booth CC. Bile-salt deconjugation and steatorrhoea in patients with the stagnant-loop syndrome. Lancet 1968; ii: $12-6$.

27 Pearce VR. The importance of duodenal diverticula in the elderly. Postgrad Med F $1980 ; 56: 777-80$.

\title{
Dorsal column stimulation in multiple sclerosis: effects on bladder and long term findings
}

\author{
C H HAWKES, R BEARD, D FAWCETT, E A PAUL, D G T THOMAS
}

\begin{abstract}
The effect of dorsal column stimulation on bladder function in 15 patients with established multiple sclerosis was analysed by urodynamic tests. Significant improvement in flow rate and urethral sphincter pressure was recorded in about two thirds. Of 31 patients examined over five years only 13 showed initial benefit from stimulation and were given permanent stimulators; of
\end{abstract}

Institute of Neurology, Queen Square, London

C H HAWKES, MD, MRCP, honorary clinical assistant, department of neurosurgical studies

E A PAUL, MSC, statistician, department of statistics and computer studies D G T THOMAS, MRCP, FRCS, senior lecturer and consultant neurosurgeon

Worthing Hospital, Sussex

R BEARD, FRCS, consultant urologist

Charing Cross Hospital, London

D FAWCETT, FRCS, senior urological registrar

Correspondence to: Dr C H Hawkes, Department of Neurology, Ipswich Hospital, Ipswich IP4 5PD. these, only three appeared to receive lasting benefit. Early complications occurred in nine patients and five had a relapse of their disease.

These results suggest that at present stimulation of the dorsal column does not have a place in the routine management of multiple sclerosis.

\section{Introduction}

Three years ago $^{1}$ we presented our initial findings of dorsal column stimulation in 19 selected patients with confirmed multiple sclerosis. The most convincing effect was on bladder control, although this was slight. We have since extended our observations, selecting particularly those patients with known bladder disorder amenable to examination.

\section{Patients and methods of assessment}

We studied 15 patients with multiple sclerosis. Three were included in our earlier publication. ' All conformed to the "definite" group of Schumacher et al, ${ }^{2}$ were aged under 55 years, and their condition was clinically stable for at least six months before the trial; they were 
reliable observers without psychiatric history and were not taking drugs that could affect bladder function.

The stimulation technique entailed the use of two epidural electrodes, as in our earlier study.'

\section{URODYNAMIC TESTS}

Virtually all urine passed was measured by an electronic flowmeter (DISA mictiograph) sited near the patient's bed. We measured mean and peak flow rates and the number of "bursts" at each voiding. An estimate of hesitancy was derived by measuring the latency between the desire to void (signalled by the patient) and start of the initial burst. Flow measurements began one week before dorsal column stimulation and continued for the first two weeks of stimulation. The following three tests were performed one week and two to four months before stimulation and again on the seventh and 14th days during stimulation.

Residual urine volume was estimated by catheterisation after normal voiding.

Filling and voiding cystometry-Subtracted detrusor pressure was recorded during filling at $10 \mathrm{ml} / \mathrm{min}$ with $35^{\circ}$ ", diodone at room temperature. Comparisons were made of the filling volume at which uninhibited contractions first occurred and the amplitude of those contractions.

Urethral pressure profiles ${ }^{3}$ were obtained, combined with assessment of response to alpha adrenergic blockade with $10 \mathrm{mg}$ intravenous phentolamine.

Assessment of the results of flow studies and pressure profiles was by statistical methods and is described below. All other urodynamic findings were evaluated by reference to an arbitrary three point scale of improvement or deterioration after discussion between neurologist and urologist.

\section{Results}

Flow studies-The mean values during the pretreatment week were compared with those during either the first or second week of treatment. Nine of the 15 patients studied showed significant improvement (p 0.01; Student's two tailed $t$ test) in one or more aspects of micturition. Either peak or mean flow was the variable most frequently noted to improve (six cases). The serial analyses of urinary flow allowed objective measurements of any response to be obtained. The data on 10 patients whose flow studies showed improvement were combined and plotted. The optimum bladder response to stimulation of the dorsal column occurred on day 6 or 7. Early failure of stimula tion in the first week caused a rapid fall to pretreatment values, whereas later failure was associated with more gradual decline.

Residual volume-Subjective analysis of residual urine in 14 patients showed slight reduction of volume in three, no change or no residual urine in nine, and a small increase in two.

Detrusor instability was judged to have lessened if uninhibited contractions occurred at a greater volume (using the arbitrary scale referred to above). Five of 14 patients showed slight improvement in this respect, eight no change, and one (whose condition relapsed during stimulation) showed deterioration.

Pressure profiles-The results of urethral pressure profiles in 10 of the 15 patients were combined with the results in seven subjects in our earlier ${ }^{1}$ publication. A significant fall in pressure occurred during the period of stimulation (Wilcoxon matched pairs test : $p=0.008$ ). All of the 12 patients given phentolamine (before treatment) showed a fall in urethral pressure within a few minutes. When the test was repeated during stimulation the absolute fall in pressure was significantly less (Wilcoxon matched pairs test: $\mathrm{p}=0.03$ ).

\section{LONG TERM RESULTS AND COMPLICATIONS}

Of 31 patients analysed over five years who were assessed for suitability for treatment by a period of trial stimulation, 13 were given permanent stimulators. Of these, only three continued to use the device at follow up four or five years later. One with leg pain of central origin continued to derive benefit, and the other two felt more mobile and experienced more satisfactory bladder control with the device switched on. In five of the remainder the disease gradually progressed and stimulation was discontinued. Two others experienced waning in the effect of stimulation within the first three months, and in three the electrodes were removed because of problems with positioning (two subjects) or skin infection (one subject).

Complications were seen in nine of the 31 patients. Three experienced frequent electrode movement or breakage, one developed a "chemical" meningitis because an electrode was inadvertently placed $\cong$ in the subarachnoid space, and five suffered relapses of their multiple $\bar{J}$ sclerosis within the first two weeks of stimulation-namely, optic D

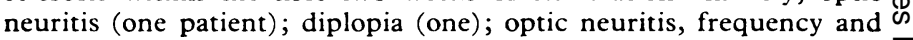
incontinence of micturition, dysphasia (one); increased leg spasticity (one); incontinence and frequency (one).

\section{Discussion}

It is generally agreed that stimulation of the dorsal column $\frac{\text { क }}{7}$

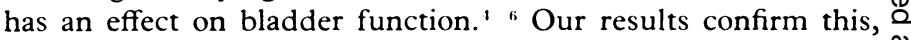
with objective findings of improvement in some two thirds of $ळ$ patients studied. The improvement in urinary flow probably $\vec{\circ}$ occurred because of lowering in urethral closing pressure, as measured by urethral pressure profile. In a few there may also $\vec{\omega}$ have been a reduction of detrusor instability. The drop in urethral closing pressure that occurs normally when the urethral 3 pressure profile is repeated after intravenous phentolamine i $(10 \mathrm{mg})$ was significantly less in patients using stimulators. Since phentolamine is an alpha adrenergic blocker it might be $\mathcal{G}^{-}$ speculated that the effect of dorsal column stimulation is to $\mathscr{G}$ reduce sympathetic outflow activity.

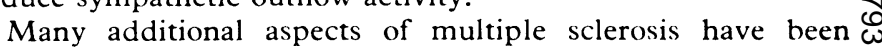
claimed to improve by others-for example, motor function and $ᄋ$ spasticity, ${ }^{4} \times{ }^{8}$ tremor, " sensory loss, ${ }^{1}$ " sexual function, ${ }^{*}$ central $\Rightarrow$ pain, ${ }^{\circ}$ leg blood flow, ${ }^{9}$ and somatosensory evoked responses. ${ }^{10} V$ Unfortunately, several of these reports have been based on $\mathbb{D}$ clinicians's subjective impressions of patients' descriptions, and $\frac{\vec{D}}{\mathbb{D}}$ where measurements have been made patients have received 3 physiotherapy ${ }^{8}$; only rarely have data been assessed statistically.

Of the components of multiple sclerosis allegedly improved, $\overrightarrow{\vec{\theta}}$ we agree that the central pain of the disease may be significantly $\infty$ relieved by stimulation of the dorsal column. Improved motor function was claimed' in five of 18 patients. The change was shown on the Kurtzte scale (which will detect only a fairly major response) and therefore is a claim of considerable benefit. The authors did not state, however, whether their patients were $\stackrel{2}{\mathscr{2}}$ encouraged or whether they received physiotherapy or any drugs $\mathbb{Q}$ that could also produce a favourable result. No permanent $\vec{F}$ record-for example, on videotape-was taken. In the same year 3 a further report appeared ${ }^{5}$ in which six of 16 patients showed lessening of muscle tone. This was assessed by subjective bedside analysis. Two previously chairbound patients became able to walk $50 \mathrm{~m}$ and $20 \mathrm{~m}$ respectively, and a further two showed increased muscle tone. Despite detailed observations on motor function and muscle tone $\mathrm{we}^{1}$ found little change. When $\frac{\sigma}{3}$ improvement did seem to take place we thought that this related to training and practice effects in highly motivated people under- $\frac{\mathrm{O}}{3}$ going a two week trial of a novel device rumoured to produce miraculous relief. Spasticity and motor function show consider- $\frac{}{2}$ able spontaneous variability and can to some extent be manipu- $\tilde{\sigma}$ lated by the patient. Conversely, bladder function, which also $D$ shows considerable fluctuation, may be mcasured objectively. We were able to allow for spontaneous variability by multiple observations and statistical analysis; hence our results on bladder N function are well founded. There are no comparable observa- $\omega$ tions on motor function, and until they are done any result in this sphere must be viewed with caution. Broadly similar conclusions of the benefits of stimulation were reached in a recently published multicentre review. ${ }^{6}$

Claims of lessening tremor and sensory deficit ${ }^{\wedge}$ have not been $\frac{0}{0}$ substantiated. A few of our male patients' reported increased $\stackrel{\mathbb{D}}{2}$ frequency of erections. We examined leg blood flow and somato- $\frac{O}{\mathbb{D}}$ sensory evoked potentials in a small number of patients ${ }^{11} 12$ and $\frac{\varrho}{Q}$ found improvement in neither. Converse findings are reported ${ }^{\prime \prime}$ but the issue has yet to be resolved.

Is dorsal column stimulation clinically worth while? Are the gains in bladder function sufficient to outweigh a relapse rate of 
$16^{\circ}{ }_{0}$ ? Had our patients reported substantial alteration in their way of life as a result of stimulation then perhaps the risk would be worth running. Although objective improvement was seen on urodynamic testing, only a minority noticed amelioration in their pattern of micturition, and in all instances this was of minor degree. No patient reported reduction of socially inconvenient symptoms such as incontinence or nocturia. Given that only three $\left(10^{\circ}{ }_{11}\right)$ of a selected group of sufferers from multiple sclerosis derived lasting benefit and that this was obtained at considerable time, expense, and inconvenience to profession and patient we conclude that at present dorsal column stimulation has no place in the routine management of multiple sclerosis. As a research procedure it holds considerable fascination, but at present further gains must be made for the patient and assessments of response need to be controlled, objective, and unemotional.

We express our sincere thanks for help and guidance during this study to Professors L Symon and W I MacDonald, Institute of Neurology, Queen Square, London, and Mr K E D Shuttleworth and Mr M I Bultitude, department of urology, St Thomas's Hospital, London. We are also indebted to the Multiple Sclerosis Society of Great Britain for financial support throughout this research.

\section{References}

1 Hawkes $\mathrm{CH}$, Wyke $\mathrm{M}$, Desmond A, Bultitude MI, Kanegaonkar GS.
Stimulation of dorsal column in multiple sclerosis. Br Med $\mathcal{f} 1980 ; 280$ : 889-91.

2 Schumacher GA, Beebe G, Kibler RT, et al. Problems of experimental trials of therapy in multiple sclerosis. Ann NY Acad Sci 1965;122: 552-68.

${ }^{3}$ Brown M, Wickham JEA. The urethral pressure profile. Br $\mathcal{F}$ Urol 1969; $41: 211-7$.

4 Illis LS, Sedgwick EM, Tallis RC. Spinal cord stimulation in multiple sclerosis: clinical results. I Neurol Neurosurg Psychiatry 1980;43:1-14.

${ }^{5}$ Read DJ, Mathews WB, Higson RH. The effect of spinal cord stimulation on function in patients with multiple sclerosis. Brain 1980;103:803-33.

6 Illis LS, Read DJ, Sedgwick EM, Tallis RC. Spinal cord stimulation in the UK. F Neurol Neurosurg Psychiatry 1983;46:299-304.

7 Cook AW, Weinstein SL. Chronic dorsal column stimulation in multiple sclerosis. NY State $\mathcal{f}$ Med 1973;73:2868-72.

Cook AW. Electrical stimulation in multiple sclerosis. Hosp Pract 1976;2: 51-8.

${ }^{9}$ Dooley DM, Kasprak M. Modification of blood flow to the extremities by electrical stimulation of the nervous system. South Med $\mathcal{F} 1976 ; 69$ : 1309-19.

${ }^{10}$ Sedgwick EM, Illis LS, Tallis RC, et al. Evoked potentials and contingent negative variation during spinal cord stimulation for multiple sclerosis. f Neurol Neurosurg Psychiatry 1980;43:15-24.

"Hawkes CH, Wyke M, Bultitude MI, Small D, Jones S, Robinson K. Epidural stimulation in 21 patients with multiple sclerosis. In: Proceedings of 6th international symposium on external control of human extremities. Belgrade: Yugoslav Committee for Electronics and Automation, 1978:603-7.

12 Hawkes CH, Fawcett D, Cooke ED, Emsom PC, Paul EA, Bowcock SA. Dorsal column stimulation in multiple sclerosis: effects on bladder, leg blood flow and peptides. Appl Neurophysiol 1981;44:62-70.

(Accepted 2 fune 1983)

\title{
Risk of early death in extremely overweight young men
}

\author{
S SONNE-HOLM, T I A SØRENSEN, U CHRISTENSEN
}

\begin{abstract}
The effect of pronounced obesity in youth on later mortality was studied in 1239 men with extreme overweight, defined as a weight $/$ height $^{2} \geqslant 31 \mathrm{~kg} / \mathrm{m}^{2}$, in the population of 331919 men liable for military service in the Copenhagen area during the period 1943-1977. A random sample of 2948 drawn from the remaining study population served as a control group. All men were followed up until November 1980 , by which time 33 deaths had occurred among the extremely overweight subjects compared with 89 in the control group. This gave a mortality ratio (observed to expected number of deaths) of $1.14(95 \%$ confidence limit 0.91-1.40) for controls with a significantly greater mortality of $1.73(95 \%$ confidence limit $1 \cdot 20-2 \cdot 41$ ) for obese subjects. The relative risk, estimated from the survival time distributions, was fairly constant around 1.6 throughout the 37 years of observation. Taking into account age at and year of entry in a regression analysis did not change the relative mortality risk. The proportion of natural death was significantly higher in the obese group than in the control group until the age of 30 but not thereafter.
\end{abstract}

Obesity Research Group, Department D 105, Herlev Hospital, University of Copenhagen, DK 2730 Herlev, Denmark

$S$ SONNE-HOLM, MD, senior registrar

T I A SØRENSEN, DR MED SCI, senior registrar

U CHRISTENSEN, $M D$, resident

Correspondence and requests for reprints to: Dr S Sonne-Holm.
Pronounced obesity in youth is a health hazard, manifesting itself particularly in a distinct increase in mortality from natural causes in early adulthood.

\section{Introduction}

The effect of obesity on mortality has been the subject of extensive research throughout this century. ${ }^{12}$ In principle the studies have been based on sampling from the population irrespective of the degree of obesity. Consequently, the number of obese subjects decreases with increasing degree of obesity and even the largest studies include rather few with morbid obesity. ${ }^{1-4}$ Owing to the increasing prevalence of obesity with advancing age this problem of design is worse the younger the population under study. Those who are severely obese in youth are, however, of particular clinical interest from both a prophylactic and therapeutic point of view. The huge life insurance studies suggest that the relative mortality risk is increasing with increasing overweight, particularly among young men. ${ }^{1}$ It is well recognised that this experience may hold only for the insured population due to the particular selection process in underwriting. In this study we used the obligatory draft board examination to collect an unbiased sample of reasonable size to allow assessment of the mortality among men considerably obese as young adults.

\section{Subjects and methods}

In Denmark all men are registered with the military authorities when they reach the age of 18 . Except for those who volunteer before this age, all are examined by the medical board within the next few 